\title{
Usefulness Evaluation of Water Extracts of Edible Plants as Compounds for the Natural Cosmetics Based on Present or Absent of Anthocyanin
}

Sung-Hee Kim, Eun-Hee Lee, Doo-Hyun Park ${ }^{*}$

Department of Beauty Art, Seokyeong University, Seoul, Korea

*Corresponding author: Doo-Hyun Park, Department of Beauty Art, Seokyeong University, 124 Seogyeong-ro, Seongbuk-gu, Seoul 02173, Korea

Tel.: +82 29407190

Fax: +82 29190345

Email: baakdoo@skuniv.ac.kr

Received July 13, 2016

Revised September 26, 2016

Accepted October 5, 2016

Published December 30, 2016

\begin{abstract}
Purpose: Aim of this study is to evaluate usefulness of water extracts obtained from some edible plants as material for natural cosmetics. Methods: River peach leaves, persimmon leaves, green tea leaves, black beans, black rice, and eggplants were dried under the same condition, and then they were selected, crushed and separated using a 50 mesh sieve. $10 \mathrm{~g}$ of the powder was suspended in $100 \mathrm{~mL}$ of distilled water and then extracted for $48 \mathrm{~h}$ at $4{ }^{\circ} \mathrm{C}$ to be used as a sample for chemical and biochemical analysis. Results: Polyphenol and flavonoid contents of green tea extracts were $9.73 \mathrm{~g} / 100 \mathrm{~g}$ and $1.28 \mathrm{~g} / 100 \mathrm{~g}$, respectively, which were about 3-6 and 2-9 times, respectively, higher than others. Anthocyanin contents of black rice peel were approximately $0.053 \mathrm{~g} / 100 \mathrm{~g}$, which were about 2-3 times higher than others. DPPH and ABTS radical scavenging activities of green tea extracts (40 mg/100 mL) were 59.5\% and 69.7\%, respectively, which were about 3-66 times and 3-30 times, respectively, higher than others. Collagenase inhibition activities of black rice peel and eggplant peel extracts $(2 \mathrm{~g} / 100 \mathrm{~mL})$ were $58.9 \%$ and 56.4\%, respectively, which were about 2-32 times and 2-31 times, respectively, higher than others. Elastase inhibition activity of eggplant peel extracts ( $2 \mathrm{~g} / 100 \mathrm{~mL}$ ) was $22.5 \%$, which was about $2-3$ times higher than others. Tyrosinase inhibition activities of persimmon and green tea extracts $(2 \mathrm{~g} / 100 \mathrm{~mL})$ were $58.8 \%$ and $42.7 \%$, respectively, which were about 2-3 times and 1.5-2 times, respectively, higher than other. Conclusion: Selection and combination of plants extracts with useful functions for beauty in company with anthocyanin and anti-oxidant may be required when usefulness of plant extracts as the material for natural cosmetics were evaluated.
\end{abstract}

Keywords: Anthocyanin, Anti-oxidant, Collagenase, Elastase, Tyrosinase

\section{Introduction}

플라보노이드계 화합물인 안토시아닌은 자외선과 산소로부터 식물의 조직을 보호하는 기능을 가지며 주로 꽃, 과일, 열매에 분 포하고 줄기와 뿌리에도 존재하는 것으로 알려져 있다. 또한, 안토 시아닌은 항산화 효과가 우수하여 지속적으로 섭취하면 건강유지 및 관리에 도움이 된다는 연구결과도 있다(Seo \& Ryu, 2012). 한 편, 안토시아닌 이외에 항산화 효과가 뛰어난 것으로 알려진 폴리 페놀과 플라보노이드는 그 유용성이 확인되어 건강식품, 차, 화장 품, 식품 첨가물 등의 형태로 다양하게 응용되고 있다(Kim et al., 2012). 특정 식물이 갖는 항산화 효과는 폴리페놀, 플라보노이드,
안토시아닌의 활성산소 소거활성에 의해 확인되는데, 이러한 생화 학적 기능은 노화예방과 면역기능 강화 효과가 있는 것으로 인식되 고 있어 식품은 물론 피부의 건강과 미용 목적으로 활용가치가 높 다(Heinrich et al., 2011; Hwang et al., 2015). 따라서 안토시아닌 을 함유한 식물과 안토시아닌을 함유하지 않은 식물로 알려진 특정 식물의 미용학적 가치를 평가하고 목적에 적합한 특정 성분과 생리 활성을 비교할 필요가 있다.

현재 고농도의 안토시아닌을 함유하고 있다는 이유로 건강식품 또는 건강식품의 재료로서 다양한 베리류가 수입 - 판매되고 있는 데 대부분이 단당류와 유기산을 함유하고 있어 그 추출물을 화장품 의 재료로 사용하기 위해서는 고비용의 정제와 가공과정이 필요하 
다. 그러나 국내에서 생산되고 있고 식품으로 이용되고 있는 검정 콩, 흑미, 가지 등의 껍질은 단당류와 유기산을 함유하지 않거나 함 량이 낮아 추출물을 직접 활용할 수 있다. 또한 항산화 활성과 다양 한 기능성 물질을 함유하는 것으로 알려진 개복숭아잎, 감잎, 녹차 잎은 물로 추출하여 건강식품으로 이용하고 있어 그 추출물을 그대 로 활용하는데 문제가 없다(Lim et al., 2008).

검정콩은 껍질에 포함된 안토시아닌의 주요 성분인 cyanidin3-glucoside (C3G)와 delphinidin-3-glucoside (D3G)가 항산화 활 성은 물론 인간의 종양세포를 억제하는 효과를 나타내는 것으로 보 고되고 있다(Meiers et al., 2001). 흑미에는 식물성 스테롤 및 다양 한 페놀성 화합물들이 함유되어 있으며 검은색을 띠는 속껍질은 다 른 곡류에 비하여 플라보노이드 및 안토시아닌이 풍부하여 항산화 활성이 우수한 것으로 알려지고 있다(Kong et al., 2008). 가지는 가지 나무에 달린 열매로 껍질 부위에 안토시아닌을 함유하고 있 고 콜레스테롤을 낮춰주는 기능이 있어 껍질을 분리하지 않고 통으 로 식품으로 사용하고 있다(Noda et al., 2000). 이와 같이 항산화 활성이 높은 검정콩, 흑미, 가지는 안토시아닌을 섭취하기 위한 목 적으로 껍질을 분리하지 않고 식품으로 이용하고 있는데 이는 껍질 부위에 생물학적으로 유해한 성분이 포함되지 않았다는 단서로서 화장품 성분으로 활용할 때 그 추출물의 특정 성분을 분리하거나 유용 성분을 정제할 필요가 없다.

한편, 항산화 기능이 우수하고 항균 활성이 있는 것으로 알려진 폴리페놀과 플라보노이드는 대부분의 식물에 포함된 기능성 성분 이지만 식물의 종에 따라 그 특성과 함량이 다르다. 개복숭아잎에 포함된 항산화 물질은 니트릴 배당체, 나링게닌, 퀴닉산, 라이코 펜, 타닌 등으로 항산화, 항균, 항염증 등의 활성이 있어 목욕물에 넣으면 땀띠나 습진을 완화하는 효과가 있는 것으로 알려져 있다 (Cha \& Lee, 2004). 감잎에는 플라보노이드 배당체, 타닌, 페놀류, 수지, 카큐민류 화합물, 비타민 C가 함유되어 있어 항산화와 항균 활성은 물론 면역력 증강, 이뇨작용, 혈압안정, 동맥경화 예방 등의 효능이 있는 것으로 보고되었다(Lee, 2014). 녹차잎에는 특히 많은 양의 폴리페놀과 플라보노이드를 함유하고 있는데, 일반적으로 폴 리페놀류에 속하는 카테킨은 용출성분의 30-40\%를 차지하고 있어 함량에 비례하는 높은 수준의 항산화 활성을 갖기 때문에 식용으로 섭취만 해도 비타민 C와 $\mathrm{E}$ 를 다량 함유하는 식품보다 효과적이라 는 보고가 있다(Cabrera et al., 2006).

이와 같이 인간의 건강증진 및 질병예방에 효과적인 성분을 함 유하는 것으로 알려진 식물의 다양한 생리활성에 근거한 유용한 성 분이 피부보호, 주름억제, 탄력유지, 미백 등과 관련된 미용학적인 기능과 연관성이 있는지를 평가하기 위해서는 안토시아닌을 함유 하거나 함유하지 않는 6 종류의 식물 추출물을 대상으로 미용목적 의 생리활성을 측정하고 특성에 따른 효과를 정량적으로 비교할 필 요가 있다. 구체적으로 안토시아닌의 유무 또는 폴리페놀, 플라보 노이드, 안토시아닌의 함량에 따른 라디칼 소거활성의 비례적 상관
관계를 측정하고 특정 생리활성(라디칼 소거활성, 콜라게나제, 엘 라스타제, 티로시나제 억제활성)에 미치는 영향을 비교 분석할 필 요가 있다.

본 연구의 목적은 안토시아닌 유무, 폴리페놀, 플라보노이드, 안 토시아닌 함량에 따른 6 가지 식물의 상호간 특정 생리활성의 유무 와 정도를 비교하여 목적하는 최적의 미용효과를 갖는 이상적인 재 료 추출물의 조합을 위한 방법론적 가능성을 제시하는 것이다. 이 러한 연구를 통하여 건강에 유용한 식품재료로 알려진 다양한 국내 산 식물의 수용성 추출물 가운데 천연 화장품 개발을 위한 우수한 효능의 식물을 선발할 뿐만 아니라, 더 나아가 목적에 따라 추출물 을 조합할 수 있는 기초적인 도구가 개발된다면 국산 화장품의 국 제적인 경쟁력을 제고하는데 도움이 될 수 있을 것으로 사료된다.

\section{Methods}

\section{1. 연구재료}

1) 천연물질 유래 유효성분을 추출하기 위해 안토시아닌을 함유하 는 것으로 알려진 국내산 검정콩(Phaseolus vulgaris), 흑미(Oryza sativa), 가지(Solanum melongena)와 폴리페놀을 함유하는 것으로 알려진 개복숭아(Prunus persica)잎, 감(Diospyros kaki)잎, 녹차 (Camellia sinensis)잎은 경동시장 광성상가(Korea) 내 약재상(개복 숭아잎, 감잎)과 식품점(검정콩, 흑미, 가지, 녹차잎)에서 생산년도 (2015년 가을), 생산지(국내산), 건조상태를 확인하여 구입하였다.

2) 연구에 사용한 반응촉매(효소), 반응기질, 표준시약, 화학반응시약, 완충용액 등은 모두 특급으로 Sigma-Aldrich (USA)에서 구매하였다.

3) 콜라게나제(collagenase), 엘라스타제(elastase), 티로시나제 (tyrosinase)는 반응촉매로 사용하였다.

4) N-Succinyl-Ala-Ala-Ala-p-nitroanilide, 4-phenylazobenzyloxycarbonyl -Pro-Leu-Gly-Pro-D-Arg, DL-tyrosine은 각각 엘라스타제, 콜라게나제, 티로시나제의 활성을 정량적으로 측정하기 위한 반응기질로 사용 하였다.

5) 타닌산(tannic acid), 쿼세틴(quercetin), 포도당시안(cyanidin3-glucoside)은 각각 폴리페놀, 플라보노이드, 안토시아닌 함량을 정량적으로 측정 비교하기 위한 표준시약으로 사용하였다.

6) 2,2'-Azino-bis (3-ethylbenzothiazoline-6-sulfonic acid) (ABTS) 5 g과 2,2-diphenyl-1-picrylhydrazyl (DPPH) $5 \mathrm{~g}$ 은 라디 칼 소거활성의 측정을 위한 화학반응시약으로 사용하였다. 
7) 인산용액(potassium phosphate, $1,000 \mu \mathrm{M}$ )과 트리즈마용액 (Tris- $\mathrm{HCl}$ buffer, $1,000 \mu \mathrm{M}$ )은 완충용액으로 사용하였다.

8) 비색법으로 효소반응, 화학반응의 결과를 측정하기 위하여 UV-Vis spectrophotometer (UV-1601; Shimadzu, Japan)를 사용하였다.

\section{2. 연구방법}

1) 추출과정

구입한 천연물질은 각각 $500 \mathrm{~g}$ 씩 용기에 담아 열에 의한 손상을 피하기 위해 $60^{\circ} \mathrm{C}$ 에서 5 일 동안 건조하였다(Larrauri et al., 1997). 건조한 천연물질(개복숭아잎, 감잎, 녹차잎, 검정콩 껍질, 흑미 껍 질, 가지 껍질)은 분쇄하여 50 mesh의 체를 통과한 미세입자를 선 별하였다. 분쇄한 각각의 재료 $10 \mathrm{~g}$ 을 유리병에 넣고 3 차 증류수를 채워 최종적으로 $100 \mathrm{~mL}$ 가 되게 한 후 밀폐한 상태에서 $200 \mathrm{rpm}$ 으로 $30 \mathrm{~min}$ 교반하여 현탁액을 만들었다. 물에 대한 용해성이 좋 은 성분을 추출하기 위해 상기의 현탁액은 $4^{\circ} \mathrm{C}$ 의 냉장고에 넣어 48 $\mathrm{h}$ 동안 저온 숙성하였다.

\section{2) 추출물의 획득 및 적용}

$48 \mathrm{~h}$ 동안 저온 숙성한 현탁액은 $4^{\circ} \mathrm{C}$ 에서 $5,000 \mathrm{rpm}$ (원심력: $3000 \times \mathrm{g}$ )으로 $90 \mathrm{~min}$ 동안 원심분리하여 침전물을 제거하고 투 명한 상등액을 분리하였다. 각 재료의 추출물은 추가의 분획과 정없이 분석대상 표준물질의 표준곡선 범위에 맞추어 적당히 희 석하여 사용하였다. $\mathrm{DPPH}$ 와 $\mathrm{ABTS}$ 소거활성을 측정할 때는 최 대 $40 \mathrm{mg} / 100 \mathrm{~mL}$ 로 희석하였으며 효소(collagenase, elastase, tyrosinase)의 억제활성을 측정할 때는 $2 \mathrm{~g} / 100 \mathrm{~mL}$ 로 희석하였다.

\section{3) Total polyphenol analysis}

시험관에 준비한 시료용액(sample) $1 \mathrm{~mL}$ 에 $0.1 \mathrm{M} \mathrm{FeCl}_{3}$ 용액 60 $\mu \mathrm{L}, 0.1 \mathrm{M} \mathrm{HCl}$ 용액 $20 \mu \mathrm{L}, 0.008 \mathrm{M} \mathrm{K}_{2} \mathrm{Fe}$ 용액 $60 \mu \mathrm{L}$ 를 첨가하고 상온에서 $10 \mathrm{~min}$ 동안 반응한 후 $720 \mathrm{~nm}$ 에서 흡광도를 측정하였 다. 시료용액 대신 각각 $2,4,6,8,10 \mu \mathrm{g} / \mathrm{mL}$ 의 타닌산용액 $1 \mathrm{~mL}$ 을 적용하여 측정한 흡광도를 기준으로 작성한 표준곡선의 기울기를 기준으로 시료의 농도를 결정하였다(Işıl Berker et al., 2010).

\section{4) Total flavonoid analysis}

시험관에 준비한 시료용액(sample) $0.2 \mathrm{~mL}$ 에 $1 \%$ aluminum chloride 용액 $40 \mu \mathrm{L}, 1 \mathrm{M}$ potassium acetate $40 \mu \mathrm{L}, 3$ 차 증 류수 $1.12 \mathrm{~mL}$ 를 첨가하고 상온에서 $10 \mathrm{~min}$ 동안 반응한 후 415 $\mathrm{nm}$ 에서 흡광도를 측정하였다. 시료용액 대신 각각 $20,40,60$, $80,100 \mu \mathrm{g} / \mathrm{mL}$ 의 쿼세틴 용액 $1 \mathrm{~mL}$ 을 적용하여 측정한 흡광도를 기준으로 작성한 표준곡선의 기울기를 기준으로 시료의 농도를 결 정하였다(Kalita et al., 2013).
5) Total anthocyanin assay

시험관에 준비한 시료용액(sample) $0.5 \mathrm{~mL}$ 에 $25 \mu \mathrm{M}$ 염산완충 용액(chloride buffer, $\mathrm{pH}$ 1.0) $4.5 \mathrm{~mL}$ 을 첨가하고 $15 \mathrm{~min}$ 동안 반 응하였다. 시험관에 준비한 시료용액(sample) $0.5 \mathrm{~mL}$ 에 $0.4 \mathrm{M}$ 초 산 완충용액(acetate buffer, $\mathrm{pH} 4.5$ ) $4.5 \mathrm{~mL}$ 을 첨가하고 $15 \mathrm{~min}$ 반응하였다. 상기 두 가지 반응액을 $510 \mathrm{~nm}$ 와 $700 \mathrm{~nm}$ 에서의 흡광 도를 측정하였다. 총 안토시아닌 함량은 cyanidin-3-glucoside 의 몰 흡광도계수를 이용하여 다음의 식에 따라 계산하였다(Lee et al., 2005)

Total anthocyanin $(\mathrm{mg} / 100 \mathrm{~g})=(\mathrm{A} \times \mathrm{MW} \times \mathrm{D} \times 100) /(\varepsilon \times \mathrm{V})$

$\mathrm{A}$ : 흡광도(absorbance value)=[A510-A700 (pH 1.0)]-[A510A700 (pH 4.5)]

MW: Cyanidin-3-glucoside 분자량(449.2)

$\mathrm{D}$ : 희석배율

$\varepsilon$ : Cyanidin-3-glucoside의 몰 흡광도계수 $\left(26,900 \mathrm{M}^{-1} \mathrm{~cm}^{-1}\right)$

$\mathrm{V}$ : 시료의 용량 $(\mathrm{mL})$

\section{6) $\mathrm{DPPH}$ 소거활성}

$\mathrm{DPPH} 100 \mu \mathrm{M}$ 을 80\% methanol에 용해하고 $2.9 \mathrm{~mL}$ 을 시험관 에 옮겨 $0.1 \mathrm{~mL}$ 시료용액과 혼합하고 $20^{\circ} \mathrm{C}$ 의 수조에 넣어 $30 \mathrm{~min}$ 동안 반응한 후 $517 \mathrm{~nm}$ 에서 흡광도를 측정한다. 대조실험은 시료 용액 대신에 동량의 증류수를 넣어 반응시킨다. $\mathrm{DPPH}$ 소거활성은 다음의 식을 이용하여 계산하였다(Brand-Williams et al., 1995).

$\mathrm{DPPH}$ radical scavenging activity $(\%)=[(\mathrm{A}-\mathrm{B}) / \mathrm{A}] \times 100$

(A: 대조군의 흡광도, $\mathrm{B}$ : 실험군의 흡광도)

\section{7) $A B T S$ 소거활성}

$7 \mu \mathrm{M}$ ABTS 용액을 $2.4 \mu \mathrm{M}$ potassium persulfate 용액과 혼합 하여 $14 \mathrm{~h}$ 동안 암소에 상온 반응하여 radical을 생성시킨 다음 0.9 $\mathrm{mL}$ 을 시험관에 옮겨 $0.1 \mathrm{~mL}$ 시료용액과 혼합하고 $20^{\circ} \mathrm{C}$ 의 수조에 넣어 $7 \mathrm{~min}$ 반응한 후 $743 \mathrm{~nm}$ 에서 흡광도를 측정한다. 대조실험 은 시료용액 대신에 동량의 증류수를 넣어 반응시킨다. ABTS 소거 활성은 다음의 식을 이용하여 계산하였다(Okoh et al., 2014).

ABTS radical scavenging activity $(\%)=[(\mathrm{A}-\mathrm{B}) / \mathrm{A}] \times 100$

(A: 대조군의 흡광도, $\mathrm{B}$ : 실험군의 흡광도)

\section{8) 콜라게나제 억제활성 측정(Collagenase inhibition assay)} 기질용액 $\left(\mathrm{pH} 7.5,100 \mu \mathrm{M}\right.$ 트리즈마 완충용액에 $4 \mu \mathrm{M} \mathrm{CaCl}_{2}$ 를 첨가하고 $0.3 \mathrm{mg} / \mathrm{mL}$ 농도로 4-phenylazobenzyloxycarbonylPro-Leu-Gly-Pro-D-Arg를 용해하여 제조) $0.25 \mathrm{~mL}$, 시료용 액 $0.1 \mathrm{~mL}, 0.2 \mathrm{mg} / \mathrm{mL}$ collagenase 용액 $0.15 \mathrm{~mL}$ 을 얼음물에 냉 각시킨 시험관에 넣고 혼합하여 반응액을 준비하였다. 대조실험을 위한 반응액은 시료 대신 3 차 증류수 $0.1 \mathrm{~mL}$ 을 첨가하였다. 준비 된 반응액은 $20^{\circ} \mathrm{C}$ 의 수조로 옮겨 $20 \mathrm{~min}$ 동안 반응한 후 $6 \%$ 구연 
산 $0.5 \mathrm{~mL}$ 를 넣어 반응을 정지시킨다. 반응 정지된 반응액에 즉시 ethyl acetate $1.5 \mathrm{~mL}$ 을 첨가하고 상등액을 취하여 $320 \mathrm{~nm}$ 에서 흡 광도를 측정하였다. 콜라게나제의 억제활성은 다음의 식을 이용하 여 계산하였다(Hwang et al., 2011).

Collagenase inhibition activity $(\%)=[(\mathrm{A}-\mathrm{B}) / \mathrm{A}] \times 100$

(A: 대조군의 흡광도, $\mathrm{B}$ : 실험군의 흡광도)

9) 엘라스타제 억제활성 측정(Elastase inhibition assay)

트리즈마 완충용액 $(\mathrm{pH} 8,200 \mu \mathrm{M}) 1.15 \mathrm{~mL}, 5 \mu \mathrm{M}$ 기질용액 (N-succinyl-Ala-Ala-Ala-p-nitroanilide을 3차 증류수에 용해) $0.3 \mathrm{~mL}, 30 \mu \mathrm{g} / \mathrm{mL}$ elastase 용액 $0.05 \mathrm{~mL}$, 시료 $0.05 \mathrm{~mL}$ 을 각각 얼음물에 냉각시킨 시험관에 넣고 혼합하여 반응액을 준비하였다. 대조실험을 위한 반응액은 시료 대신 3 차 증류수 $0.05 \mathrm{~mL}$ 을 첨가 하였다. 준비된 반응액은 $25^{\circ} \mathrm{C}$ 의 수조로 옮겨 $15 \mathrm{~min}$ 동안 반응한 후 $4{ }^{\circ} \mathrm{C}$ 이하의 얼음물에 넣어 반응을 정지시키고 $410 \mathrm{~nm}$ 에서 흡광 도를 측정하였다. 엘라스타제의 억제활성은 다음의 식을 이용하여 계산하였다(Moon et al., 2010).

Elastase inhibition activity $(\%)=[(\mathrm{A}-\mathrm{B}) / \mathrm{A}] \times 100$

(A: 대조군의 흡광도, $\mathrm{B}$ : 실험군의 흡광도)

\section{0) 티로시나제 억제활성 측정(Tyrosinase inhibition assay)}

인산 완충용액(pH 6.8, $20 \mu \mathrm{M}) 1.15 \mathrm{~mL}, 30 \mu \mathrm{M}$ 기질용액 $(0.1 \mathrm{M}$ $\mathrm{HCl}$ 에 용해한 DL-tyrosine) $0.1 \mathrm{~mL}, 50$ unit tyrosinase 용액 0.05 $\mathrm{mL}$, 시료 $0.05 \mathrm{~mL}$ 을 각각 얼음물에 냉각시킨 시험관에 넣고 혼합 하여 반응액을 준비하였다. 대조실험을 위한 반응액은 시료 대신 3 차 증류수 $0.05 \mathrm{~mL}$ 을 첨가하였다. 준비된 반응액은 $37^{\circ} \mathrm{C}$ 의 수조로 옮겨 $2 \mathrm{~h}$ 동안 반응한 후 $4^{\circ} \mathrm{C}$ 이하의 얼음물에 넣어 반응을 정지시 키고 $475 \mathrm{~nm}$ 에서 흡광도를 측정하였다. 티로시나제의 억제활성은 다음의 식을 이용하여 계산하였다(Sripathi \& Lalitha, 2016).

Tyrosinase inhibition assay $(\%)=[(\mathrm{A}-\mathrm{B}) / \mathrm{A}] \times 100$

(A: 대조군의 흡광도, $\mathrm{B}$ : 실험군의 흡광도)

11) 모든 실험은 3회 반복하였으며 결과는 평균과 표준편차로 표기하였다.

\section{Results and Discussion}

\section{1. 재료 추출물의 폴리페놀, 플라보노이드, 안토시아닌의 함량 비교}

식용, 건강식품 또는 약용으로 사용하는 식물의 항산화 물질의 함량과 성분은 기본적으로 종류에 따라 다르고 측정하는 방법과 시 기에 따라 오차가 발생할 가능성이 있다. 이러한 오차의 기회를 최 소화하고 특정 재료의 상대적인 항산화 활성을 비교하기 위해서는 동일한 추출과 분석 방법을 적용하여 동시에 수행할 필요가 있다. 또한 항산화 활성을 갖는 성분이 다양하기 때문에 성분에 대한 분 석도 동시에 이루어지는 것이 합리적이라고 사료된다. 이러한 이유 로 항산화 활성이 우수한 것으로 알려진 개복숭아잎, 감잎, 녹차잎, 검정콩 껍질, 흑미 껍질, 가지 껍질에 포함된 폴리페놀, 플라보노이 드, 안토시아닌의 함량을 측정 비교하였다(Yao et al., 2013).

건조중량 기준 $100 \mathrm{~g}$ 의 개복숭아잎, 감잎, 녹차잎, 검정콩 껍질, 흑미 껍질, 가지 껍질에 포함된 폴리페놀 함량은 Table 1에서 보는 바와 같이 각각 $2.66,2.94,9.73,2.62,1.53,2.15 \mathrm{~g}$ 이며 플라보노 이드는 각각 $0.56,0.72,1.28,0.34,0.25,0.14 \mathrm{~g}$ 으로 나타났다. 특히, 녹차잎의 폴리페놀과 플라보노이드 함량이 가장 높게 나타 나 다른 시료에 비해 최대 6 배 이상의 차이를 보였다. 그러나 폴리 페놀과 같이 항산화 활성을 갖는 것으로 알려진 플라보노이드 상대 적인 함량은 전체적으로 폴리페놀에 비해 크게 낮았는데 이는 폴리 페놀의 유도체의 다양성 $(4,000$ 가지 이상)과 함량이 비례하기 때문 으로 생각된다(Virgili \& Marino, 2008). 플라보노이드는 폴리페놀 의 범주에 속하지만 1 개의 pyran과 2 개의 벤젠고리를 포함하는 총 3 개의 고리형 화합물로 anthocyanin, flavone, flavonol, isoflavone 등 4 가지의 유도체를 갖기 때문에 그 함량 또한 유도체의 다양성에 비례하여 폴리페놀에 비해 상대적인 함량이 낮을 것으로 추정된다 (Ververidis et al., 2007).

안토시아닌은 담자주색을 띠는 검정콩, 흑미, 가지에서만 선택 적으로 검출되었는데 건조한 재료 $100 \mathrm{~g}$ 기준으로 $0.027,0.053$, $0.016 \mathrm{~g}$ 으로 폴리페놀과 플라보노이드에 비해 크게 낮은 것으로 나 타났다. 이러한 함량의 차이는 플라보노이드계에 속하는 안토시 아닌이 콩, 흑미, 가지의 껍질에만 선택적으로 분포하여 질량 대

Table 1. Contents of anti-oxidative compounds in extracts obtained from 6 plant samples that are river peach leaves, persimmon leaves, green tea leaves, black bean peel, black rice peel, and eggplant peel

\begin{tabular}{lcccccc}
\hline \multirow{2}{*}{ Division } & \multicolumn{5}{c}{ Contents $(\mathrm{g} / 100 \mathrm{~g}$ as dry weight) } \\
\cline { 2 - 7 } Polyphenol & $2.66 \pm 0.1^{*}$ & $2.94 \pm 0.1^{*}$ & $9.73 \pm 0.2^{*}$ & $2.62 \pm 0.1^{*}$ & $1.53 \pm 0.1^{* *}$ & $2.15 \pm 0.1^{*}$ \\
Flavonoid & $0.56 \pm 0.03^{*}$ & $0.72 \pm 0.05^{*}$ & $1.28 \pm 0.05^{*}$ & $0.34 \pm 0.04^{* *}$ & $0.25 \pm 0.03^{*}$ & $0.14 \pm 0.03^{*}$ \\
Anthocyanin & 0 & 0 & 0 & $0.027 \pm 0.001^{* *}$ & $0.053 \pm 0.002^{*}$ & $0.016 \pm 0.001^{*}$ \\
Total contents & $3.22 \pm 0.10^{*}$ & $3.66 \pm 0.11^{*}$ & $11.01 \pm 0.305^{*}$ & $2.987 \pm 0.11^{* *}$ & $1.833 \pm 0.11^{*}$ & $2.305 \pm 0.10^{*}$ \\
\hline
\end{tabular}

${ }^{*} p<.05,{ }^{* *} p<.001$ 
비 상대적인 함량이 낮기 때문으로 사료된다. 한편, 개복숭아잎, 감 잎, 녹차잎 추출물에서 안토시아닌은 검출되지 않았으나 폴리페놀 과 플라보노이드의 함량이 상대적으로 높아 항산화 활성을 기준으 로 재료를 선택한다면 감잎이나 녹차잎이 유용할 수 있다. 따라서 폴리페놀과 플라보노이드는 그 함량의 차이가 있지만 식물에 포함 된 보편적인 항산화 활성을 갖는 성분으로 평가할 수 있고 안토시 아닌은 특이한 색깔을 띠는 특정한 식물의 특정 부위(열매 껍질, 과 일 껍질 등)에 선택적으로 함유되어 있는 성분으로 우수한 항산화 활성 때문에 건강식품의 재료로서 활용가치가 있다(Weisel et al., 2006).

상기의 분석결과를 근거로 판단할 때 검정콩 껍질, 흑미 껍질, 가지 껍질의 폴리페놀과 플라보노이드 상대적인 함량은 녹차잎에 비해 낮지만 폴리페놀, 플라보노이드, 안토시아닌을 모두 함유하 고 있어 항산화 활성 성분의 다양성을 기준으로 평가하면 화장품의 재료로서 상대적인 가치는 녹차잎에 비해 우수하다고 판단된다. 그 러나 목적하는 항산화 성분과 높은 항산화 활성을 충족하기 위해서 는 한 가지의 식물 재료보다 각각의 항산화 성분의 함량과 활성이 우수한 몇 가지 식물 재료를 선택하여 혼합하는 것이 합리적이라고 판단된다(Zillich et al., 2015).

\section{2. 라디칼 소거 활성}

특정한 항산화 활성을 갖는 것으로 알려진 성분을 포함하는 식 물 추출물의 실질적인 항산화 성분함량과 항산화 활성의 상관관계 는 활성산소와 같은 라디칼의 속성을 갖는 $\mathrm{DPPH}$ 와 $\mathrm{ABTS}$ 를 적용 하여 측정하는 것이 바람직하다. 측정결과에 따르면 Table 2 와 같 이 6 가지 재료의 상대적인 라디칼 소거활성은 폴리페놀, 플라보노 이드 또는 안토시아닌의 단일 항산화 물질의 함량(Table 1)과 상대 적인 라디칼 소거활성은 비례적인 상관관계가 없는 것으로 나타났 다. 또한 안토시아닌의 함량과 라디칼 소거활성 또한 비례적인 상 관성이 없는 것으로 나타났다. 이러한 결과는 본 연구에서 사용한 개복숭아잎, 감잎, 녹차잎, 검정콩 껍질, 흑미 껍질, 가지 껍질의 추 출물의 $\mathrm{DPPH}$ 또는 $\mathrm{ABTS}$ 의 라디칼 소거활성은 폴리페놀, 플라보
노이드 또는 안토시아닌의 함량 보다는 각각의 재료 식물에 포함된 항산화 활성을 갖는 특정 성분에 의해 영향을 받을 수 있다는 것을 보여주는 것이다.

한편, 상기 6 가지 수용성 추출물의 $\mathrm{DPPH}$ 소거활성과 $\mathrm{ABTS}$ 소 거활성의 차이는 두 종류의 라디칼의 산화-환원전위의 차이 $(0.42$ volt versus $\mathrm{NHE}$ )에 비례하는 반응성의 차이에 의한 것으로 특정 천연물질의 상대적인 항산화 활성을 비교하는데 문제가 없는 것으 로 판단된다. 그러나 특이적으로 $\mathrm{DPPH}$ 또는 $\mathrm{ABTS}$ 에 대한 감수성 이 약하거나 반응성이 없는 항산화 물질의 라디칼 소거활성을 측정 할 때는 두 가지 라디칼을 적용하는 것이 반응의 기회가 높기 때문 에 동시에 적용하는 것이 유리하다. 본 연구에서는 6 가지 재료의 절대적인 라디칼 소거활성이 아닌 상대 활성을 비교하기 위한 목 적으로 동일한 조건, 시간에 추출한 수용성 성분에 대한 $\mathrm{DPPH}$ 와 $\mathrm{ABTS}$ 소거능을 측정하여 공통적으로 높은 활성산소의 소거활성을 갖는 재료를 선택할 수 있는 판단 지표로서 $\mathrm{ABTS}$ 와 $\mathrm{DPPH}$ 를 동시 에 적용하였기 때문에 상대적인 측정값의 차이는 중요한 인자가 아 니다. 따라서 상기의 6 가지 재료의 수용성 추출물 가운데 천연 화 장품의 제조를 위한 성분으로서 $\mathrm{DPPH}$ 와 $\mathrm{ABTS}$ 를 이용한 라디칼 소거능이 상대적으로 우수한 녹차잎을 선택하는 것이 합리적이라 고 판단되지만 화학적으로 합성된 라디칼의 소거활성의 측정 결과 와 인체의 피부에서 생화학적인 활성산소 소거활성의 일치성을 확 인할 수 없기 때문에 폴리페놀, 플라보노이드, 안토시아닌을 모두 포함하는 검정콩 껍질과 녹차잎을 혼합하는 것이 합리적이라고 사 료된다(Amić et al., 2003; Bao et al., 2005).

\section{3. 생리활성}

정상적인 상태에서 콜라게나제는 질병에 의한 손상 회복 및 피 부 조직 재생 등 피부 조직의 구조유지를 위해 필요하다. 그러나 자 외선, 감염, 면역 이상, 노화에 의한 생리 기능 감소 등에 의해 콜 라게나제가 비정상적으로 활성이 촉진되면 콜라겐을 분해하여 주 름의 생성을 촉진한다. 엘라스타제 또한 콜라게나제와 유사한 활 성 촉진 반응에 의해 엘라스틴 섬유를 분해하여 피부의 탄력을 감

Table 2. Radical scavenging activities of extracts obtained from 6 plant samples that are river peach leaves, persimmon leaves, green tea leaves, black bean peel, black rice peel, and eggplant peel

\begin{tabular}{|c|c|c|c|c|c|c|}
\hline \multirow{2}{*}{ Division } & \multicolumn{6}{|c|}{ Relative activity (\%) } \\
\hline & River peach leaves & Persimmon leaves & Green tea leaves & Black bean peel & Black rice peel & Eggplant pee \\
\hline $\begin{array}{l}\text { Sample contents } \\
(\mathrm{mg} / 100 \mathrm{~mL})\end{array}$ & $\begin{array}{l}400 \\
(40)\end{array}$ & $\begin{array}{l}400 \\
(40)\end{array}$ & 40 & 40 & $\begin{array}{l}400 \\
(40)\end{array}$ & $\begin{array}{l}400 \\
(40)\end{array}$ \\
\hline $\begin{array}{l}\text { DPPH radical } \\
\text { scavenging activity }\end{array}$ & $\begin{array}{c}12.9 \pm 0.1^{*} \\
(1.29)^{\bullet}\end{array}$ & $\begin{array}{c}18.2 \pm 0.1^{*} \\
(1.82)^{\circ}\end{array}$ & $59.5 \pm 0.1^{*}$ & $18.0 \pm 0.1^{*}$ & $\begin{array}{c}9.1 \pm 0.1^{*} \\
(0.9)^{\circ}\end{array}$ & $\begin{array}{c}13.7 \pm 0.1^{*} \\
(1.37)^{\bullet}\end{array}$ \\
\hline $\begin{array}{l}\text { ABTS radical } \\
\text { scavenging activity }\end{array}$ & $\begin{array}{c}60.6 \pm 0.2^{*} \\
(6.06)^{\circ}\end{array}$ & $\begin{array}{c}91.4 \pm 0.4^{*} \\
(9.14)^{\bullet}\end{array}$ & $69.7 \pm 0.3^{*}$ & $20.9 \pm 0.1^{* *}$ & $\begin{array}{c}26.2 \pm 0.1^{*} \\
(2.62)^{\bullet}\end{array}$ & $\begin{array}{c}23.5 \pm 0.3^{*} \\
(2.35)^{\bullet}\end{array}$ \\
\hline
\end{tabular}

Value in parentheses was adjusted to $40 \mathrm{mg} / 100 \mathrm{~mL}$ of sample contents for relative comparison.

${ }^{*} p<.05,{ }^{* *} p<.01$ 
소시킨다. 따라서 콜라게나제와 엘라스타제의 비정상적인 활동을 억제할 수 있는 물질을 함유하는 화장품을 사용하면 피부의 주름을 억제하고 탄력을 유지하는데 도움이 될 수 있을 것이다(Hwang et al., 2011).

상기 6 가지 수용성 추출물의 콜라게나제와 엘라스타제 억제활 성을 비교한 결과 Table 3 과 같이 상대적인 콜라게나제의 억제활 성이 가장 우수한 물질은 흑미와 가지 껍질 추출물로 약 $58.9 \%$ 와 $56.4 \%$ 이었고 상대적인 엘라스타제의 억제활성이 가장 우수한 물 질은 가지 껍질 추출물로 약 $22.5 \%$ 이었다. 이러한 결과에 근거하 여 주름개선을 위한 기능성 화장품을 제조할 때 흑미 껍질 추출물 과 가지 껍질 추출물을 사용하는 것이 가장 효과적일 것으로 판단 된다. 한편, 멜라닌의 생성을 촉매하는 효소 가운데 핵심적인 기능 을 하는 티로시나제를 억제하는 성분이 화장품에 포함되면 피부의 미백효과를 기대할 수 있는 것으로 보고되고 있는데 Table 3에서 보는 바와 같이 감잎의 수용성 추출물의 티로시나제 억제활성은 약 $58.8 \%$ 로 다른 재료에 비해 상대적으로 높은 것으로 나타났다(Lee $\& \mathrm{HeO}, 2012)$. 이러한 결과를 근거로 판단하면 미백 효과를 기대할 수 있는 화장품을 제조할 때 감잎 추출물을 적용하는 것이 효과적 이라고 판단된다.

이와 같이 6 가지 재료 가운데 기능성 화장품의 제조를 위한 성 분으로서 최적의 조합을 선별하기 위해서 항산화 물질의 함량, 안 토시아닌 함량, 항산화 활성, 효소 억제 활성 등 4 개의 범주로 구 분하여 비교할 필요가 있지만 안토시아닌의 함량과 항산화 활성 (DPPH, ABTS 소거활성)의 상관관계(Table 1과 2)를 감안하면 안 토시아닌 보다는 효소 억제 활성을 선택의 기준으로 적용할 필요가 있다. 따라서 각각의 범주 내에서 폴리페놀과 플라보노이드의 함량 은 녹차잎 추출물을, 활성산소 소거능은 녹차잎 추출물을, 콜라게 나제 활성 억제를 위해서 흑미 또는 가지 껍질 추출물을, 엘라스타 제 활성 억제를 위해서 가지 껍질 추출물을, 티로시나제 활성 억제 를 위해서 감잎 추출물을 사용하는 것이 효과적이라고 판단된다. 이상의 결과를 종합하면 항산화 활성, 피부탄력 유지, 주름억제, 미
백 등의 효과를 동시에 구현하기 위해서는 기능성 화장품을 제조할 때 녹차잎 추출물, 가지 껍질 추출물, 감잎 추출물을 조합하여 적용 하는 것이 바람직하다고 판단된다.

이와 같이 식품, 건강식품, 약용으로 이용되는 식물의 추출물 가 운데 피부의 미용효과를 위해 유용하다고 판단되는 성분이나 기능 성을 함유하는 물질에 대한 연구는 특정한 목적성 성능을 선택하 는데 유용하기 때문에 상기의 6 가지 식물재료 이외에 다른 식물 에 대한 연구가 필요하다고 판단된다. 그러나 피부에 직접 적용하 는 화장품의 성분으로서 유해성, 부작용의 가능성, 만성 면역질환 의 원인 등을 고려하여 가능한 가장 보편적으로 국내에서 서식 또 는 재배되는 식용식물 가운데서 부작용의 사례가 낮은 반면 기능성 이 우수한 것으로 알려진 재료를 선택하는 것이 안전하다고 사료된 다(Brand-Garnys et al., 2007; Chan et al., 2010).

\section{Conclusion}

인간에 의해 오랫동안 식품, 건강식품, 또는 약용으로 사용되어 온 식물의 특정한 조직이나 기관은 보편적인 관점에서 인간의 건강 에 유해한 영향을 미치거나 부작용의 원인이 될 가능성이 낮다. 식 용이나 약용으로 사용되는 식물(잎, 줄기, 열매 등)의 추출물은 보 편적으로 건강한 사람에게 부작용을 유발할 가능성이 낮기 때문에 화장품을 제조할 때 첨가물로 사용하는데 문제가 없을 것이다. 그 러나 식물 추출물을 첨가한 화장품을 제조할 때 부작용의 가능성만 을 고려한다면 천연 또는 기능성 화장품으로서의 가치가 없기 때문 에 보편적으로 화장품을 사용하는 사람이 추구하는 목적성 이상의 기능성을 갖는 것이 필요하다.

기능성 화장품의 제조업자 또는 회사가 추구하는 가장 효과적인 기능은 항산화에 의한 피부보호 및 건강유지, 콜라겐과 엘라스틴의 손상 억제를 통한 피부탄력 및 주름 생성지연, 멜라닌 생성억제에 의한 피부의 미백유지 또는 관리 등으로 판단된다. 이와 같이 다목

Table 3. Physiological activities of extracts obtained from 6 plant samples that are river peach leaves, persimmon leaves, green tea leaves, black bean peel, black rice peel, and eggplant peel

\begin{tabular}{|c|c|c|c|c|c|c|}
\hline \multirow{2}{*}{ Division } & \multicolumn{6}{|c|}{ Relative activity (\%) } \\
\hline & River peach leaves & Persimmon leaves & Green tea leaves & Black bean peel & Black rice peel & Eggplant pee \\
\hline $\begin{array}{l}\text { Sample contents } \\
(\mathrm{g} / 100 \mathrm{~mL})\end{array}$ & $\begin{array}{l}10 \\
(2)\end{array}$ & 2 & 2 & 2 & 2 & 2 \\
\hline Collagenase inhibition & $\begin{array}{c}9.10 \pm 0.2^{*} \\
(1.82)^{\bullet}\end{array}$ & 0.00 & $30.9 \pm 0.5^{*}$ & $32.3 \pm 0.4^{*}$ & $58.9 \pm 0.5^{*}$ & $56.4 \pm 0.5^{*}$ \\
\hline Elastase inhibition & 0.00 & $6.89 \pm 0.1^{* *}$ & $8.78 \pm 0.2^{*}$ & $10.5 \pm 0.3^{*}$ & $10.2 \pm 0.2^{*}$ & $22.5 \pm 0.3^{*}$ \\
\hline Tyrosinase inhibition & $\begin{array}{c}92.4 \pm 0.2^{*} \\
(18.4)^{\circ}\end{array}$ & $58.8 \pm 0.4^{*}$ & $42.7 \pm 0.2^{*}$ & $28.1 \pm 0.2^{* *}$ & $21.3 \pm 0.2^{*}$ & $19.3 \pm 0.2^{*}$ \\
\hline
\end{tabular}

Value in parentheses was adjusted to $2 \mathrm{~g} / 100 \mathrm{~mL}$ of sample contents for relative comparison.

${ }^{*} p<.05,{ }^{* *} p<.001$ 
적의 기능성을 갖는 화장품을 제조하기 위해서는 목적하는 기능성 을 갖는 성분을 함유하는 식물의 발굴과 그 추출물의 효과가 입증 되어야 하는데 단일 식물을 선택하여 개별적으로 효과를 입증하기 위해 분석한 자료는 분석방법, 추출방법, 분석환경 등의 차이에 의 한 오차의 변수가 크기 때문에 동시에 수집하고 추출하여 동일한 방법을 이용한 분석이 이루어져야 한다. 또한 각 식물 재료의 목적성 기능이 확인되면 상대적인 효능을 비교하여 최선의 식물 재료를 조 합하여 그 추출물을 이용한 화장품의 제조와 적용실험을 할 필요가 있다.

본 연구에서는 기초적인 수준에서 안토시아닌을 함유하지 않는 개복숭아잎, 감잎, 녹차잎과 안토시아닌을 함유하는 검정콩 껍질, 흑미 껍질, 가지 껍질 등 총 6 개의 식물 재료를 대상으로 유용한 항 목을 화학적으로 분석하여 기능성 화장품을 위한 목적성 조합의 가 능성을 확인하였다. 녹차잎 추출물은 안토시아닌을 함유하지 않지 만 폴리페놀과 플라보노이드의 함량은 다른 재료에 비해 각각 3-6 배와 2-9배 높은 것으로 나타났다. 흑미 껍질 추출물의 안토시아닌 함량은 검정콩 껍질 추출물과 가지 껍질 추출물에 비해 2-3배 높 은 것으로 나타났다. $\mathrm{DPPH}$ 와 $\mathrm{ABTS}$ 소거활성을 기준으로 측정한 녹차잎 추출물의 상대적인 항산화 활성은 다른 재료에 비해 각각 3-66배, 3-30배 높은 것으로 나타났다. 생리활성과 관련해서는, 흑 미 껍질 추출물과 가지 껍질 추출물의 콜라게나제 억제활성은 다른 재료의 추출물에 비해 각각 약 2-32배, 2-31배 높았다. 가지 껍질 추출물의 엘라스타제 억제활성은 2-3배 수준이었다. 감잎과 녹차 잎 추출물의 티로시나제 억제활성은 다른 재료에 비해 각각 2-3배, 1.5-2배로 나타났다.

이상의 결과에서 보는 바와 같이 본 연구에서 사용한 6 가지 재 료를 기준으로 평가하면 항산화 활성, 라디칼 소거활성, 콜라게나 제 억제활성, 엘라스타제 억제활성, 티로시나제 억제활성을 모두 충족하는 기능성을 갖는 천연 화장품을 제조하기 위해서는 최소 3 종류(녹차잎, 감잎, 가지 껍질)의 추출물을 조합하여 사용하는 것이 바람직하다고 판단한다. 결론적으로 본 연구에서 사용한 재료 이 외에 건강에 유용한 식품재료로 알려진 국내산 식물 추출물 가운데 천연 화장품 개발을 위한 기능성이 우수한 재료를 선발하고, 목적 에 따라 조합할 수 있는 기술적 기반이 구축된다면 국산 화장품의 국제적인 경쟁력을 높이고 관련 산업의 발전에 도움이 될 수 있을 것으로 사료된다.

This work is part of the Sung-Hee Kim's Ph.D. thesis at the Seokyeong University, Seoul, Korea.

\section{References}

Amić D, Davidović-Amić D, Bešlo D, Trinajstić N. Structureradical scavenging activity relationships of flavonoids. Croatica Chemica Acta, 76: 55-61, 2003.

Bao J, Cai Y, Sun M, Wang G, Corke H. Anthocyanins, flavonols, and free radical scavenging activity of Chinese bayberry (Myrica rubra) extracts and their color properties and stability. Journal of Agricultural and Food Chemistry, 53: 2327-2332, 2005.

Brand-Garnys EE, Denzer H, Meijer H, Brand HM. Flavonoids: a review for cosmetic application. part two. Journal of Applied Cosmetology, 25: 145-159, 2007.

Brand-Williams W, Cuvelier ME, Berset C. Use of a free radical method to evaluate antioxidant activity. LWT-Food Science and Technology, 28: 25-30, 1995.

Cabrera C, Artacho R, Giménez R. Beneficial effects of green tea-a review. Journal of the American College of Nutrition, 25: 79-99, 2006.

Cha BC, Lee EH. Antioxidant and antiinflammation activities of Prunus persica tree extracts. Korean Journal of Medicinal Crop Science, 12: 289-294, 2004.

Chan CF, Lien CY, Lai YC, Huang CL, Liao WC. Influence of purple sweet potato extracts on the UV absorption properties of a cosmetic cream. Journal of Cosmetic Science, 61: 333-341, 2010.

Heinrich M, Dhanji T, Casselman I. Açai (Euterpe oleracea Mart.)-a phytochemical and pharmacological assessment of the species' health claims. Phytochemistry Letters, 4: 10-21, 2011.

Hwang J, Yun JK, Han KH, Do E, Lee JS, Lee EJ, Kim JB, Kim MR. Anti-oxidation and anti-aging effect of mixed extract from Korean medicinal herbs. The Korea Journal of Herbology, 26: 111-117, 2011.

Hwang JY, Beak HG, Park BR, Kim YC. Anti-aging efficacy of Tradescantia reflexa methanol extract in human dermal fibroblasts. Journal of Investigative Cosmetology, 11: 2532, 2015.

Işıl Berker K, Güçlü K, Tor I, Demirata B, Apak R. Total antioxidant capacity assay using optimized ferricyanide/ prussian blue method. Food Analytical Methods, 3: 154168, 2010.

Kalita P, Barman TK, Pal TK, Kalita R. Estimation of total flavonoids content (TFC) and anti oxidant activities of 
methanolic whole plant extract of Biophytum sensitivum Linn. Journal of Drug Delivery and Therapeutics, 3: 3337, 2013.

Kim EJ, Choi JY, Yu M, Kim MY, Lee S, Lee BH. Total polyphenols, total flavonoid contents, and antioxidant activity of Korean natural and medicinal plants. Korean Journal of Food Science and Technology, 44: 337-342, 2012.

Kong S, Choi Y, Lee SM, Lee J. Antioxidant compounds and antioxidant activities of the methanolic extracts from milling fractions of black rice. Journal of the Korean Society of Food Science and Nutrition, 37: 815-819, 2008.

Larrauri JA, Rupérez P, Saura-Calixto F. Effect of drying temperature on the stability of polyphenols and antioxidant activity of red grape pomace peels. Journal of Agricultural and Food Chemistry, 45: 1390-1393, 1997.

Lee DJ, Heo JR. Anti-oxidant activity and whitening activity of Punica granatum leaf extracts. Journal of Investigative Cosmetology, 8: 235-241, 2012.

Lee J, Durst RW, Wrolstad RE. Determination of total monomeric anthocyanin pigment content of fruit juices, beverages, natural colorants, and wines by the $\mathrm{pH}$ differential method: collaborative study. Journal of Association of Official Analytical Chemists International, 88: 1269-1278, 2005.

Lee JH. Anti-oxidant and anti-inflammatory effects of Diospyros kaki Thumb leaves extracts. Asian Journal of Beauty and Cosmetology, 12: 719-724, 2014.

Lim JH, Kim BK, Park CE, Park KJ, Kim JC, Jeong JW, Jeong SW. Antioxidative and antimicrobial activities of persimmon leaf tea and green tea. Journal of the East Asian Society of Dietary Life, 18: 797-804, 2008.

Meiers S, Kemény M, Weyand U, Gastpar R, von Angerer E, Marko D. The anthocyanidins cyanidin and delphinidin are potent inhibitors of the epidermal growth-factor receptor. Journal of Agricultural and Food Chemistry, 49: 958-962, 2001.

Moon JY, Yim EY, Song G, Lee NH, Hyun CG. Screening of elastase and tyrosinase inhibitory activity from Jeju island plants. EurAsian Journal of BioSciences, 4: 41-53, 2010.

Noda Y, Kneyuki T, Igarashi K, Mori A, Packer L. Antioxidant activity of nasunin, an anthocyanin in eggplant peels. Toxicology, 148: 119-123, 2000.

Okoh SO, Asekun OT, Familoni OB, Afolayan AJ. Antioxidant and free radical scavenging capacity of seed and shell essential oils extracted from Abrus precatorius (L). Antioxidants, 3: 278-287, 2014.

Seo ES, Ryu GC. An effect of visual acuity protection by natural pigment (anthocyanine) extracted from fermented purple sweet potato. Journal of Korean Ophthalmic Optics Society, 17: 395-401, 2012.

Sripathi SK, Lalitha P. Keratolytic molecule aided inhibition of DNA damage and tyrosinase activity of a herbal formulation. International Journal of BioSciences and Technology, 9: 7-14, 2016.

Ververidis F, Trantas E, Douglas C, Vollmer G, Kretzschmar G, Panopoulos N. Biotechnology of flavonoids and other phenylpropanoid-derived natural products. part I: chemical diversity, impacts on plant biology and human health. Biotechnology Journal, 2: 1214-1234, 2007.

Virgili F, Marino M. Regulation of cellular signals from nutritional molecules: a specific role for phytochemicals, beyond antioxidant activity. Free Radical Biology and Medicine, 45: 1205-1216, 2008.

Weisel T, Baum M, Eisenbrand G, Dietrich H, Will F, Stockis JP, Kulling S, Rüfer C, Johannes C, Janzowski C. An anthocyanin/polyphenolic-rich fruit juice reduces oxidative DNA damage and increases glutathione level in healthy probands. Biotechnology Journal, 1: 388-397, 2006.

Yao SL, Xu Y, Zhang YY, Lu YH. Black rice and anthocyanins induce inhibition of cholesterol absorption in vitro. Food and Function, 4: 1602-1608, 2013.

Zillich OV, Schweiggert-Weisz U, Eisner P, Kerscher M. Polyphenols as active ingredients for cosmetic products. International Journal of Cosmetic Science, 37: 455-464, 2015. 


\section{국문초록}

\section{안토시아닌 유무에 근거한 천연화장품의 소재로서 식용식물 추출물의 유용성 평가}

김성희, 이은희, 박두현

서경대학교 미용예술학과, 서울, 한국

목적: 본 연구의 목적은 안토시아닌의 유무에 따른 특정 식용식물 추출물의 폴리페놀과 플라보노이드 함량, 항산화 활성 및 콜라게 나제, 엘라스타제, 티로시나제의 억제활성을 비교하여 화장품 소재로서의 유용성을 평가하는 것이다. 방법: 개복숭아잎, 감잎, 녹 차잎, 검정콩, 흑미, 가지를 동일한 조건에서 건조하였으며, 미세분말을 얻기 위하여 파쇄한 후 50 메쉬의 체를 사용하여 여과하였 다. 재료분말 $10 \mathrm{~g}$ 을 $100 \mathrm{~mL}$ 의 증류수에 현탁하여 $4^{\circ} \mathrm{C}$ 에서 $48 \mathrm{~h}$ 동안 추출하였고 화학 및 생화학적 분석을 위한 시료로서 사용하 였다. 결과: 녹차잎 추출물의 폴리페놀과 플라보노이드의 함량은 각각 $9.73 \mathrm{~g} / 100 \mathrm{~g}$ 과 $1.28 \mathrm{~g} / 100 \mathrm{~g}$ 으로 다른 재료에 비해 각각 약 3-6배, 2- 9 배 높았으며 흑미 껍질 추출물의 안토시아닌 함량은 $0.053 \mathrm{~g} / 100 \mathrm{~g}$ 으로 다른 재료에 비해 약 2-3배 높았다. DPPH와 ABTS 소거활성을 기준으로 측정한 녹차잎 추출물 $(40 \mathrm{mg} / 100 \mathrm{~mL})$ 의 라디칼 소거활성은 각각 약 $59.5 \%$ 와 $69.7 \%$ 로 다른 재료의 추 출물에 비해 상대적인 활성이 각각 3-66배, 3 - 30 배 높았다. 흑미 껍질 추출물과 가지 껍질 추출물 $(2 \mathrm{~g} / 100 \mathrm{~mL})$ 의 콜라게나제 억 제활성은 각각 약 $58.9 \%$ 와 $56.4 \%$ 로 다른 재료의 추출물에 비해 약 2-32배, 2-31배 높았다. 가지 껍질 추출물 $(2 \mathrm{~g} / 100 \mathrm{~mL})$ 의 엘 라스타제 억제활성은 약 $22.5 \%$ 로 다른 재료에 비해 2-3배 활성이 높았다. 감잎과 녹차잎 추출물 $(2 \mathrm{~g} / 100 \mathrm{~mL})$ 의 티로시나제 억제 활성은 약 $58.8 \%$ 와 $42.7 \%$ 로 다른 재료에 비해 각각 약 2- 3 배, $1.5-2$ 배 높았다. 결론: 천연 화장품의 재료로서 식물 추출물의 가 치를 평가할 때 안토시아닌과 항산화 효과는 물론 미용을 위해 유용한 기능성을 기준으로 재료를 선별하고 조합하는 것이 필요할 것으로 사료된다.

핵심어: 안토시아닌, 항산화, 콜라게나제, 엘라스타제, 티로시나제

\section{참고문헌}

공수현, 최용민, 이선미, 이준수. 흑미의 도정분획 메탄올 추출물의 항산화 성분 및 항산화 효과. 한국식품영양과학회지, 37 :

815-819, 2008.

김은진, 최주연, 유미리, 김미영, 이상현, 이복희. 자생식물과 생약자원 추출물의 폴리페놀, 플라보노이드 함량 및 항산화 활

성 탐색. 한국식품과학회지, 44: 337-342, 2012.

서은선, 유근창. 발효 자색고구마 추출 천연색소(anthocyanine)에 의한 시력보호 효과. 한국안광학회지, 17: 395-401,

2012.

이동자, 허정록. 석류잎 추출액의 항산화 작용과 미백작용. 대한미용학회지, 8: 235-241, 2012.

이정희. 감잎추출물의 항산화 및 항염증 효과. 아시안뷰티화장품학술지, 12: 719-724, 2014.

임정호, 김범근, 박찬은, 박기재, 김종찬, 정진웅, 정승원. 감잎차와 녹차의 항산화 및 항균 활성 비교. 동아시아식생활학회

지, 18: 797-804, 2008.

차배천, 이은희. 야생 복숭아나무 추출물의 항산화 및 항염증 효과. 한국약용작물학회지, 12: 289-294, 2004.

황재규, 윤종국, 한길환, 도은주, 이진상, 이은주, 김종부, 김미려. 한약재 복합 추출물이 항산화 및 항노화에 미치는 영향. 대 한본초학회지, 26: 111-117, 2011.

황지연, 백현기, 박별례, 김영철. 인체피부섬유아세포에서 자주달개비 메탄올 추출물의 항노화 효능. 대한미용학회지, $11:$ 25-32, 2015. 


\section{中文摘要}

\section{基于花青素存在与否研究食用植物提取物作为天然化妆品原料的有效性评价研究}

金成姬，李銀姬，朴斗鉉

西京大学 美容艺术學科, 首尔, 韩国

目的: 根据花青素 (anthocyanin) 存在与否, 比较研究特定食用植物提取物的多酚和类黄酮含量, 抗氧化活性以及 胶原 酶、弹性蛋白酶、酪氨酸酶的抑制活性，从而判断作为化妆品原料的有用性。方法: 在相同条件下，对江桃树叶（river peach leaves）、柿子树叶、绿茶叶、黑豆、黑米、茄子等进行干燥、选拔并粉碎，利用50 mesh过滤网分离。将 $10 \mathrm{~g}$ 粉 末倒入 $100 \mathrm{~mL}$ 蒸馏水中, 在温度为 $4^{\circ} \mathrm{C}$ 时, 经过 $48 \mathrm{~h}$ 提取, 提取物用于化学以及生化学分析。结果: 绿茶叶提取物的多酚 和类黄酮含量分别为 $9.73 \mathrm{~g} / 100 \mathrm{~g} 、 1.28 \mathrm{~g} / 100 \mathrm{~g}$, 相比其他原料分别高出3-6倍, 2-9倍。黑米皮提取物的花青素含量为 $0.053 \mathrm{~g} / 100 \mathrm{~g}$, 相比其他原料高出 2-3倍。关于 DPPH和ABTS消除活性研究, 绿茶叶提取物 $(40 \mathrm{mg} / 100 \mathrm{~mL}$ ) 的消除自 由基活性分别为 $59.5 \%$ (DPPH) ， 69.7\% (ABTS），相比其他原料分别高出3-66倍, 3-30倍。黑米果皮提取物（2 g/100 $\mathrm{mL}$ ) 的胶原酶抑制活性为 $58.9 \%$ ，相比其他原料高出2-32倍。茄子皮提取物（2 g/100 mL）的胶原酶抑制活性为 $56.4 \%$, 相比其他原料高出2-31倍。茄子皮提取物 $(2 \mathrm{~g} / 100 \mathrm{~mL})$ 的弹性蛋白酶抑制活性为 $22.5 \%$ ，相比其他原料高出2-3倍。江桃 树叶提取物 $(2 \mathrm{~g} / 100 \mathrm{~mL})$ 的酪氨酸酶的抑制活性为 $58.8 \%$, 相比其他原料高出2-3倍。绿茶叶提取物 $(2 \mathrm{~g} / 100 \mathrm{~mL})$ 的酪 氨酸酶的抑制活性为 $42.7 \%$, 相比其他原料高出 $1.5-2$ 倍。结论: 评价天然材料的植物提取物时, 不仅要评价花青素和抗氧 化效果, 也需按照美容功效的基准来选择植物进行组合。

关键词: 花青素, 抗氧化, 胶原酶, 弹性蛋白酶, 酪氨酸酶 